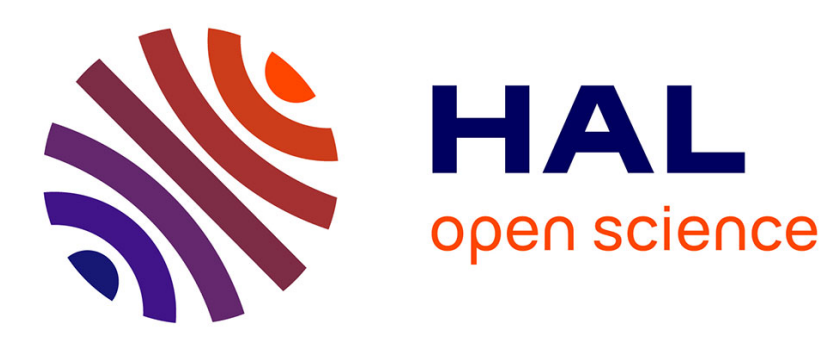

\title{
Variability in pathogenicity of Melampsora allii-populina expressed on poplar cultivars
}

\author{
Pascal Frey, Jean Pinon
}

\section{To cite this version:}

Pascal Frey, Jean Pinon. Variability in pathogenicity of Melampsora allii-populina expressed on poplar cultivars. European Journal of Forest Pathology, 1997, 27, pp.397-407. hal-02690690

\section{HAL Id: hal-02690690 \\ https://hal.inrae.fr/hal-02690690}

Submitted on 1 Jun 2020

HAL is a multi-disciplinary open access archive for the deposit and dissemination of scientific research documents, whether they are published or not. The documents may come from teaching and research institutions in France or abroad, or from public or private research centers.
L'archive ouverte pluridisciplinaire HAL, est destinée au dépôt et à la diffusion de documents scientifiques de niveau recherche, publiés ou non, émanant des établissements d'enseignement et de recherche français ou étrangers, des laboratoires publics ou privés. 


\title{
Variability in pathogenicity of Melampsora allii-populina expressed on poplar cultivars
}

\author{
By P. FreY and J. PINON \\ Pathologie Forestière, Ecosystèmes Forestiers, INRA, 54280 Champenoux, France
}

\begin{abstract}
Summary
A collection of 42 isolates of Melampsora allii-populina was established. Fourteen isolates were collected from various poplar cultivars over several French localities and 28 isolates from the alternate hosts (Allium spp., Arum spp. and Muscari comosum) obtained from nature or after inoculation. These isolates were inoculated in the laboratory on a large range of poplar cultivars belonging to several species. No isolate proved pathogenic on all cultivars and many qualitative interactions were observed between isolates and cultivars. This is the first evidence for the existence of physiological races within this fungus. No link was found between pathogenicity on poplar and on the alternate hosts.

Among the inoculated cultivars, at least three were susceptible to all isolates (Beaupré, Candicans and Robusta), whereas the following showed qualitative reactions to the inoculated isolates: Altichiero, Carpaccio, Cima, Fritzi Pauley, I 154, Isières, Luisa Avanzo, NL 2842, Rap and Spijk. Race-specific resistance to $M$. allii-populina (i.e. resistance to some races of the pathogen, but not to the others) has been found in two North American species (Populus deltoides and Populus trichocarpa) which have never coevolved with this fungus. The results are discussed in comparison with Melampsora laricipopulina.
\end{abstract}

\section{Introduction}

Rust fungi are known to exhibit variability in pathogenicity and generally described as composed of formae speciales (according to the range of species infected) and as physiological races (according to the range of cultivars infected) (MCINTOSH and WATSON 1982; AGRIOS 1988). This is well known in the genus Melampsora Castagne.

The first evidence for the variability in pathogenicity in a Melampsora species was given by FLOR (1935) who described physiological races within Melampsora lini (Schum.) Desm. Poplars may be infected by various Melampsora species and VAN VLOTEN (1949) first reported the existence of physiological races within Melampsora larici-populina Kleb. More recently, many new races were discovered within this species when complete resistance (i.e. resistance to all known races of the pathogen) of selected cultivars was broken down (STeenackers 1982; Pinon and Bachacou 1984; Pinon et al. 1987; Pinon and Peulon 1989; PinON and LefĖVRe 1994; STEENACKERS et al. 1994; PinON 1995).

MAGNANI (1965) reported a possible variability in pathogenicity on poplar within $M$. allii-populina Kleb. and suggested the possible existence of physiological races. He studied isolates from different geographical origins and found differences in pathogenicity between them. However, no clear qualitative interactions between clones and isolates were described. In a review on the variability in the susceptibility to Melampsora rusts within the genus Populus, PINON (1992) reported conflicting conclusions from various authors about the susceptibility of cultivated poplar clones to $M$. allii-populina. The inconsistency of the behaviour of some cultivars suggested the possible existence of races within $M$. alliipopulina. 
Variability in $M$. allii-populina has also been described according to the pathogenicity on the alternate hosts. VIENNOT-BOURGIN (1937) described two formae speciales: $f$. sp. alliipopulina, which was pathogenic on Arum spp. and Allium spp. and f. sp. muscaridispopulina, which was pathogenic only on Muscari comosum Mill. and Allium sphaerocephalum L. Furthermore, the author reported the presence of thin spinules at the apex of the urediniospores of the f. sp. muscaridis-populina. Later, DupIAs (1965) suggested the existence of a third forma specialis, f. sp. typica which was pathogenic on Allium spp., Arum spp. and $M$. comosum. This latter statement is questionable, since the poplar leaves studied by DUPIAS could have borne teliospores of both f. sp. allii-populina and f. sp. muscaridispopulina.

In the present study, we have tested the pathogenicity of various isolates of $M$. alliipopulina collected from poplar and from the alternate hosts on a wide range of poplar cultivars in order to determine the presence of physiological races.

\section{Materials and methods}

\subsection{Poplar cultivars}

The cultivars to be inoculated were chosen among (1) those which were currently infected in nature by $M$. allii-populina and (2) those whose behaviour towards $M$. allii-populina appeared inconsistent according to the literature (PINON 1992; PINON and VALADON 1997). These cultivars belong to various species from sections Aigeiros and Tacamahaca of genus Populus L. and their intra- and inter-sectional hybrids (Table 1). The plants were propagated from dormant cuttings planted in a greenhouse in 5 -l containers in a mixture of peat and sand (1/1) complemented with limestone (to adjust $\mathrm{pH}$ around 5.5) and fertilized with Nutricote Total 13.13.13.2 (Fertil, Paris, France).

\subsection{Alternate hosts}

Arum italicum Mill. was collected from the field in nature and transplanted in the nursery, while seeds and bulbs of Allium cepa L., M. comosum and A. sphaerocephalum were purchased and grown in the greenhouse in the same substrate used to grow poplars.

\subsection{Isolates from poplar}

The poplar isolates were collected from naturally infected leaves (Table 2). Each isolate was derived from an individual uredinium selected from one leaf. The isolates were cultured in

Table 1. Poplar species and cultivars tested for their reaction to Melampsora allii-populina isolates

\begin{tabular}{|ll|}
\hline Populus species & Cultivars \\
\hline P. $\times$ euramericana (Dode) Guinier & Altichiero, Cima, Carpaccio, Bellini, Bellotto, \\
& Büchig, Ghoy, I 154, I 214, Isières, Luisa \\
& Avanzo, Primo, Rintheim, Robusta, Spijk, \\
P. nigra L. & Tiepolo, Véronèse \\
P. trichocarpa Torr. \& Gray & Italica \\
P. trichocarpa $\times$ P. deltoides Bartr. & Fritzi Pauley \\
$P$. trichocarpa $\times$ P. maximowiczii Henry & Beaupré, Boelare, Rap, Raspalje, Unal \\
P. candicans Ait. & NL 2842 \\
& Candicans \\
\hline
\end{tabular}


Table 2. Origin of the isolates of Melampsora allii-populina collected from poplar

\begin{tabular}{|llll|}
\hline Isolate & Cultivar & Locality & Year \\
\hline ALT B & Altichiero & Bordeaux & 1989 \\
BPR G & Beaupré & Guéméné-Penfao & 1989 \\
BPR N & Beaupré & Nancy & 1989 \\
BIN G & Bellini & Guéméné-Penfao & 1989 \\
BLT G & Bellotto & Guéméné-Penfao & 1988 \\
BLR G & Boelare & Guéméné-Penfao & 1989 \\
CND G & Candicans & Guéméné-Penfao & 1989 \\
CRP B & Carpaccio & Bordeaux & 1989 \\
214 G & I 214 & Guéméné-Penfao & 1988 \\
ITL NT & Italica & Nantes & 1988 \\
PRM G & Primo & Guéméné-Penfao & 1989 \\
RNT G & Rintheim & Guéméné-Penfao & 1989 \\
RBS NT & Robusta & Nantes & 1988 \\
UNL G & Unal & Guéméné-Penfao & 1989 \\
\hline
\end{tabular}

the laboratory by inoculating healthy leaves of the cultivar Robusta which was susceptible to all isolates of $M$. allii-populina. Because $M$. larici-populina was also present on several poplar cultivars, all isolates were inoculated on the cultivar Beaupré which was, at this time, totally resistant to $M$. larici-populina and susceptible to all isolates of $M$. allii-populina. All the isolates were partially dehydrated at $5^{\circ} \mathrm{C}$ under vacuum in a desiccator for 1 week, and then cryopreserved in liquid nitrogen until further use.

\subsection{Isolates from the alternate hosts}

Isolates were either collected from naturally infected alternate hosts in April-May, or obtained after artificial inoculation of the alternate hosts (Table 3). Poplar leaves bearing telia on their lower surface were collected in September-October and over-wintered in the nursery in baskets made of plastic mesh. The leaves bearing telia were transferred to the laboratory in March-April, when telia were ready to germinate. Container-grown alternate hosts were inoculated in the laboratory. For each individual plant a separate source of inoculum was used (i.e. leaves from one poplar cultivar collected in one place). Leaves bearing telia were soaked in tap water for $3 \mathrm{~h}$ and then laid on a plastic net placed over the alternate host, telia facing the plants to be inoculated. The poplar leaves were then covered with wet filter paper and each container was wrapped with a plastic bag for one night. Plants were incubated in a growth room at approximately $20^{\circ} \mathrm{C}$ under fluorescent light (16h photoperiod, $25 \mu \mathrm{mol} / \mathrm{m}^{2} \cdot \mathrm{s}$ ). Aecia developed 2-3 weeks later. Isolates were obtained from individual aecia and cultured on the susceptible poplar cultivar Beaupré and subsequently provided unrediniospores for the pathogenicity test on poplar cultivars.

\subsection{Morphological features}

Urediniospore morphology of isolates originated from various alternate hosts and from poplars were compared using light and scanning electron microscopy. For scanning electron microscopy, the urediniospores were frozen at $-60^{\circ} \mathrm{C}$ and then freeze-dried at $-10^{\circ} \mathrm{C}$ for $24 \mathrm{~h}$, allowed to reach room temperature, mounted on aluminium stubs with conductive glue containing graphite (Leit C, Boiziau Distribution, Selles-sur-Cher, France), and then overlaid with a 10-nm conducting carbon coat (metallizer Balzer's CED/020, Boiziau 
Table 3. Origin of the isolates of Melampsora allii-populina from alternate hosts

\begin{tabular}{|c|c|c|c|}
\hline Alternate host & Isolate & $\begin{array}{l}\text { Natural infection } \\
\text { (locality) }\end{array}$ & $\begin{array}{l}\text { Artificial inoculation } \\
\text { (cultivar/locality) }\end{array}$ \\
\hline Allium vineale $\mathrm{L}$. & $\begin{array}{l}4 \\
8\end{array}$ & $\begin{array}{l}\text { Nancy } \\
\text { Fontainebleau }\end{array}$ & \\
\hline Allium cepa $\mathrm{L}$. & $\begin{array}{l}3 \\
3 \text { gr } \\
\text { A } 51 \\
\text { A } 3 \\
\text { E } 4 \\
\text { N } 2 \\
\text { O } 1\end{array}$ & Nancy & $\begin{array}{l}\text { Beaupré/Nancy } \\
\text { Isières/Nancy } \\
\text { Isières/Nancy } \\
\text { Robusta/Guéméné } \\
\text { Isières/Guéméné } \\
\text { Ghoy/Guéméné }\end{array}$ \\
\hline Arum italicum Mill. & 6 & Nancy & \\
\hline Arum maculatum L. & 9 & Fontainebleau & \\
\hline Allium sphaerocephalum L. & $\begin{array}{l}\text { A } 52 \\
\text { C } 5 \\
\text { D } 5 \\
\text { G } 5 \\
\text { L } 5 \\
\text { N } 5\end{array}$ & & $\begin{array}{l}\text { Isières/Nancy } \\
\text { Robusta/Nancy } \\
\text { Beaupré/Nancy } \\
\text { Ghoy/Guéméné } \\
\text { Beaupré/Guéméné } \\
\text { Isières/Guéméné }\end{array}$ \\
\hline Muscari comosum Mill. & $\begin{array}{l}10 \\
11 \\
\text { D } 1 \\
\text { D } 3 \\
\text { H } 1 \\
\text { L } 3 \\
\text { N } 1 \text { B } \\
\text { O } 4 \\
\text { R } 1 \\
\text { S } 4 \\
\text { T } 1 \text { B }\end{array}$ & $\begin{array}{l}\text { Fontainebleau } \\
\text { Nancy }\end{array}$ & $\begin{array}{l}\text { Beaupré/Nancy } \\
\text { Beaupré/Nancy } \\
\text { Beaupré/Guéméné } \\
\text { Beaupré/Guéméné } \\
\text { Isières/Guéméné } \\
\text { Ghoy/Guéméné } \\
\text { Beaupré/Nancy } \\
\text { Robusta/Guéméné } \\
\text { Robusta/Nancy }\end{array}$ \\
\hline
\end{tabular}

Distribution). The urediniospores were examined under a Stereoscan $90 \mathrm{~B}$ scanning electron microscope (Cambridge Instrument, Cambridge, UK) operating a $25 \mathrm{kV}$.

\subsection{Pathogenicity tests on poplar}

Urediniospore suspensions were prepared in water agar $(0.1 \mathrm{~g} / \mathrm{l})$ and adjusted to 10000 spores $/ \mathrm{ml}$. After shaking, the spore suspension was sprayed, using a compressed air spraying device, on leaf disks cut from leaves of poplars grown in the greenhouse. A first test was performed on six 12-mm diameter disks per isolate. Any negative or doubtful reaction was confirmed by a second test on $30-\mathrm{mm}$ diameter disks. The disks were floated on water in Petri dishes, abaxial surface uppermost. The Petri dishes were incubated at $20^{\circ} \mathrm{C}$ under constant illumination (fluorescent light, $25 \mu \mathrm{mol} / \mathrm{m}^{2} \times \mathrm{s}$ ). During the 2 weeks following the inoculation the disks were observed daily to detect symptoms: absence of symptoms or necrotic flecks in the case of incompatibility, or uredinia formation in the case of compatibility. 


\section{Results}

\subsection{Morphological features}

All the isolates, whether they were collected from poplar or from alternate hosts, exhibited the same morphology under the microscope. When inoculated on poplar, isolates from $M$. comosum and $A$. sphaerocephalum produced typical urediniospores - smooth at the apex and echinulate on the remaining wall. The observation of urediniospores of $M$. allii-populina f. sp. muscaridis-populina with a scanning electron microscope did not reveal the presence of any spinules at the apex of the spores as described by VIENNOT-BOURGIN (1937) (Fig. 1). Our observation was confirmed by G. DuPIAS (pers. com.) on his own specimens of $M$. allii-populina f. sp. muscaridis-populina. Thus, it seems that the description of special morphological features for this forma specialis is questionable. Furthermore, an examination of specimens from VIENNOT-BOURGIN's herbarium did not reveal the presence of any spinules at the apex.

\subsection{Pathogenicity of the isolates collected from poplar}

Of the 24 cultivars inoculated, none appeared completely resistant to all isolates. Sixteen cultivars became infected with all isolates: Beaupré, Bellini, Bellotto, Boelare, Büchig, Candicans, Ghoy, I 214, Italica, Primo, Raspalje, Rintheim, Robusta, Tiepolo, Unal and Véronèse. On the other cultivars, a wide range of reactions was observed, ranging between susceptibility and complete resistance depending on the isolate. Eight cultivars (NL 2842, Luisa Avanzo, Cima, Carpaccio, Altichiero, Fritzi Pauley, Isières, and I 154) proved to be susceptible only to some isolates and displayed different interaction patterns with the isolates tested (Table 4). The 14 isolates were assigned to nine different pathogenicity groups according to their virulence on the eight cultivars. Compared with leaf disc tests with $M$. larici-populina, some reactions were unstable.

\subsection{Pathogenicity of the isolates collected from alternate hosts}

Some cultivars appeared susceptible to all isolates from alternate hosts: Beaupré, Robusta, Candicans, I 154, and Isières. The same range of reactions was observed as with the isolates

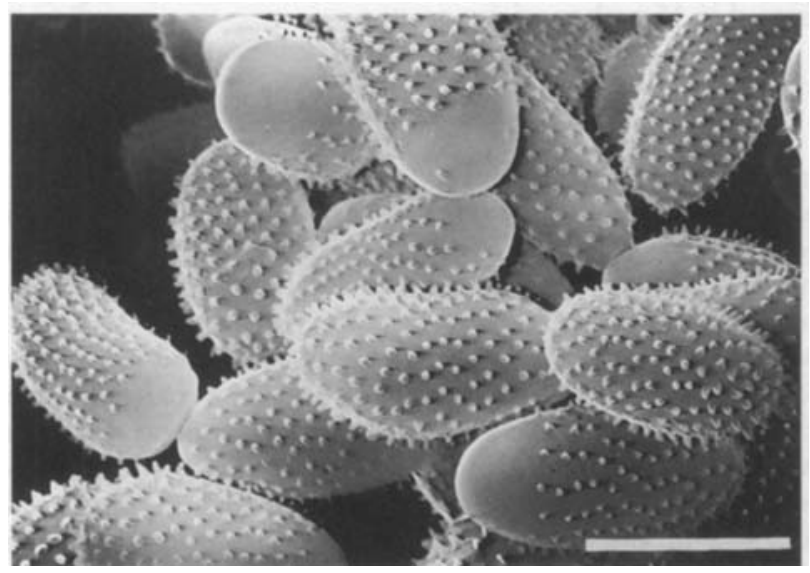

Fig. 1. Scanning electron micrograph of urediniospores of Melampsora allii-populina f. sp. muscaridispopulina. The spores are typically smooth at the apex and echinulate on the remaining wall. Bar $=20 \mu \mathrm{m}$ 
Table 4. Interactions between isolates of Melampsora allii-populina from poplar and poplar cultivars. NT = not tested; $-=$ no infection; $+=$ slight and irregular infection; $++=$ slight $(1-10$ uredinia per leaf disk) but reproducible infection; $+++=$ heavy infection and sporulation (more than 10 uredinia per leaf disk); ()$=$ test performed only once

\begin{tabular}{|c|c|c|c|c|c|c|c|c|c|}
\hline \multirow[b]{2}{*}{ Isolate } & \multicolumn{8}{|c|}{ Inoculated cultivar } & \multirow[b]{2}{*}{$\begin{array}{l}\text { Patho- } \\
\text { genicity } \\
\text { group }\end{array}$} \\
\hline & $\begin{array}{c}\mathrm{NL} \\
2842\end{array}$ & $\begin{array}{c}\text { Luisa } \\
\text { Avanzo }\end{array}$ & Cima & Carpaccio & Altichiero & $\begin{array}{l}\text { Fritzi } \\
\text { Pauley }\end{array}$ & Isières & I 154 & \\
\hline BLT G & + & - & +++ & +++ & +++ & ++ & ++ & +++ & A \\
\hline ALT B & $(-)$ & + & +++ & ++ & +++ & $(-)$ & + & - & $\mathrm{B}$ \\
\hline BPR G & $(-)$ & + & ++ & +++ & +++ & $(-)$ & +++ & ++ & $\mathrm{C}$ \\
\hline BPR N & - & + & +++ & +++ & +++ & ++ & +++ & +++ & $\mathrm{D}$ \\
\hline CRP B & - & +++ & +++ & +++ & +++ & NT & ++ & + & $\mathrm{D}$ \\
\hline ITL NT' & - & - & +++ & ++ & ++ & + & +++ & +++ & $\mathrm{E}$ \\
\hline CND G & - & - & +++ & +++ & +++ & +++ & +++ & +++ & $\mathbf{E}$ \\
\hline RBS NT & $(-)$ & - & + & + & + & ++ & ++ & + & $\mathbf{E}$ \\
\hline UNL G & - & - & $++t$ & +++ & +++ & ++ & ++ & $++t$ & $\mathbf{E}$ \\
\hline PRM G & - & - & +++ & +++ & +++ & NT & +++ & +++ & $\mathrm{E}$ \\
\hline $\mathrm{BLN} \mathrm{G}$ & - & - & - & ++ & +++ & + & - & ++ & $F$ \\
\hline BLR G & - & - & - & +++ & +++ & - & ++ & +++ & $\mathrm{G}$ \\
\hline RNT G & - & - & - & +++ & $(-)$ & ++ & +++ & +++ & $\mathrm{H}$ \\
\hline $214 G$ & + & - & - & - & ++ & - & - & ++ & I \\
\hline
\end{tabular}

from poplars. Six cultivars (NL 2842, Luisa Avanzo, Cima, Carpaccio, Altichiero, and Fritzi Pauley), which exhibited clear interactions with the isolates from poplar, confirmed their behaviour after inoculation with the isolates from alternate hosts (Table 5). In addition, crs Rap and Spijk also exhibited qualitative interactions with the isolates from alternate hosts. Twelve different pathogenicity groups could be differentiated by their range of virulences on these poplar cultivars. Furthermore, several pathogenicity groups contained isolates collected from different alternate hosts and thus belonging to both formae speciales as defined by VIENNOT-BOURGIN (1937).

Table 6 summarizes the qualitative interactions found between the eight poplar cultivars and the $42 \mathrm{M}$. allii-populina isolates collected either from poplar or from alternate hosts, which were clustered in 15 pathogenicity groups.

\section{Discussion}

These results provide the first clear evidence of the existence of physiological races within $M$. allii-populina, as was already known for $M$. larici-populina. Hitherto, no physiological races have been described in $M$. allii-populina, probably because no loss of complete resistance was reported. In fact, no selection was conducted in Europe for complete resistance to this species, in contrast to M. larici-populina (PINON and VALADON 1997). This is in accordance with the fact that, in the present study, we found no cultivar resistant to all the isolates of $M$. allii-populina. Several physiological races were found within isolates from both origins (poplar and alternate hosts). The number of virulence per isolate was variable. Some isolates exhibited up to five virulences (e.g. isolates 4, 6, 9 and 10), whereas isolate G5 was found with only two virulences on the range of inoculated cultivars. We found many different combinations of virulences and avirulences. According to the number of interactions found between isolates and cultivars, it may be concluded that more races can exist, as it is the case for M. larici-populina (PINON 1995).

Comparing the virulences found within isolates from both poplar and alternate hosts, it 


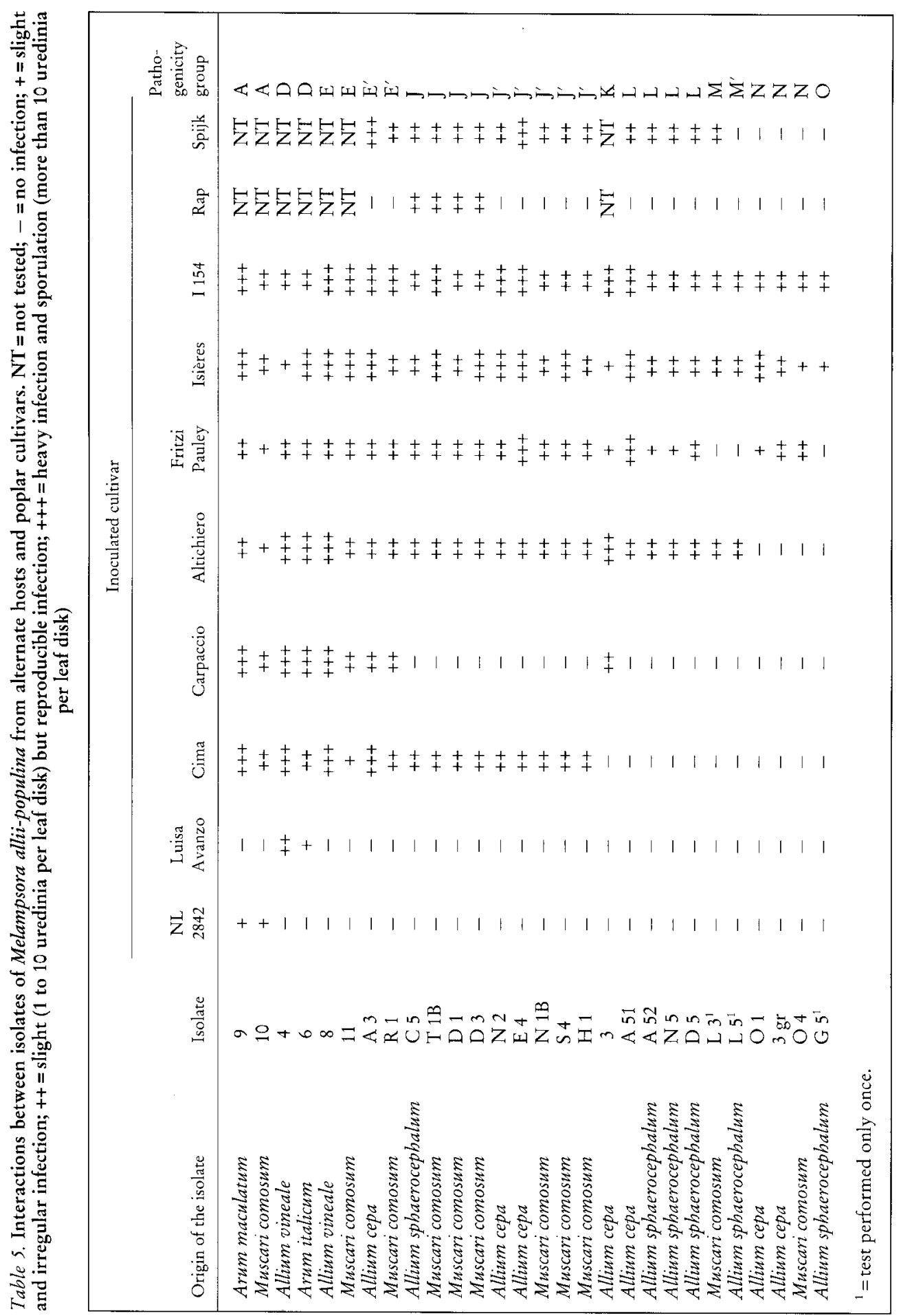




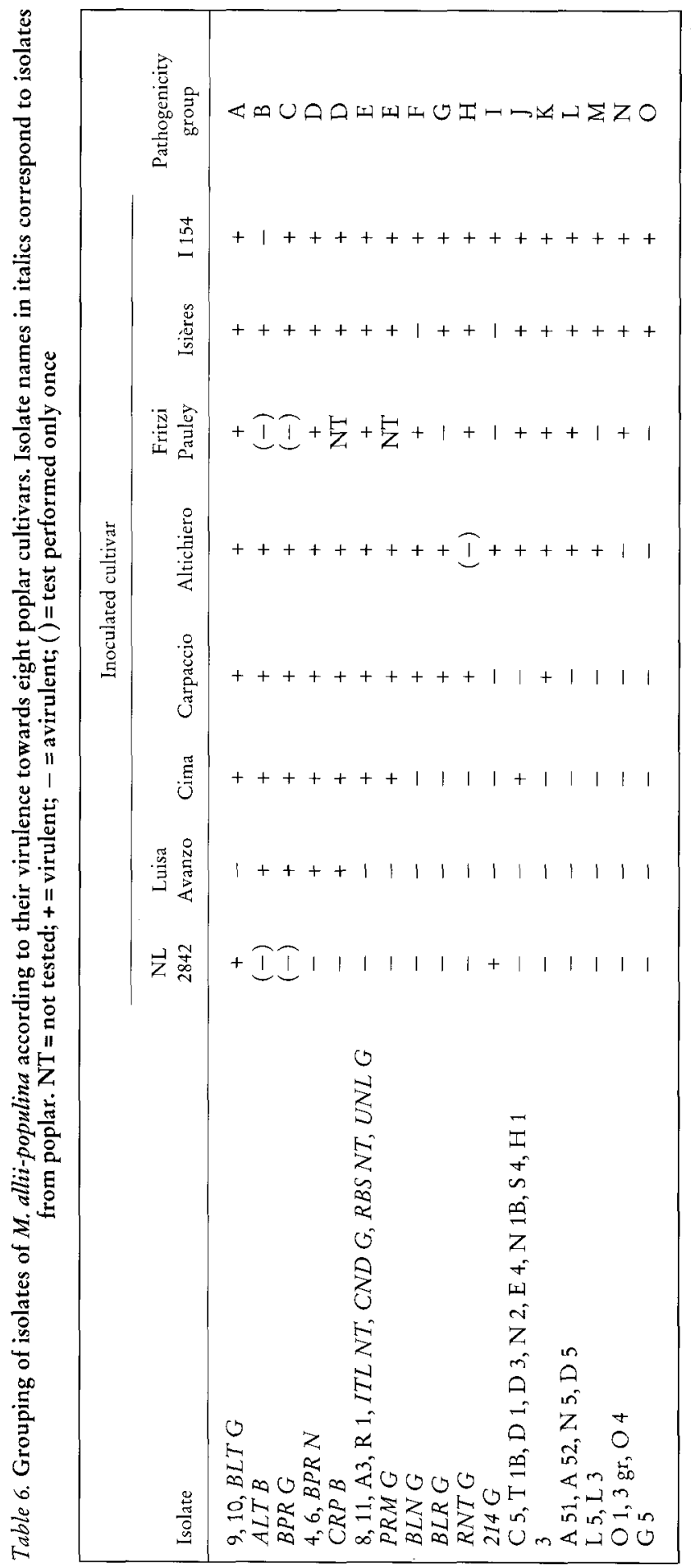


appears that the same races can be found in isolates from both origins (Table 6). Furthermore, no link appeared between the pathogenicity group of the isolates and the forma specialis to which they may belong (Table 5). Presently, neither morphological features of urediniospores, nor pathogenicity on poplar can be used to distinguish the forma specialis. This suggests that fungal genes involved in the infection of poplar and of the alternate host may be different.

Comparing the pathogenicity of the isolates from poplar and from the alternate hosts, it may be concluded that, at least three cultivars are susceptible to all isolates: cvs Robusta, Beaupré and Candicans. This result is in accordance with the observation that these cultivars are routinely infected severely in nature by $M$. allii-populina (PINON 1992; PINON and VALADON 1997; J. PINON unpublished data). However, the behaviour of these three cultivars towards physiological races of M. larici-populina is not the same (PINON 1995): cv. Robusta is susceptible to all known races, while cvs Candicans and Beaupré can be infected only by isolates having the relevant virulence (virulence 2 and 7 , respectively). These results suggest that the genes which confer race-specific resistance to $M$. laricipopulina are different from those which confer resistance to $M$. allii-populina.

The following cultivars exhibited race-specific resistance (i.e. resistance to some races of the pathogen, but not to the others) to some isolates of $M$. allii-populina and can thus be used to characterize isolates of this species: cvs NL 2842, Luisa Avanzo, Cima, Carpaccio, Altichiero, Fritzi Pauley, Isières, I 154, Rap and Spijk. These cultivars belong to different botanical types (Table 1). Cultivars Luisa Avanzo, Cima, Carpaccio, Altichiero, Isières, I 154, and Spijk belong to the hybrid P. $\times$ euramericana (Dode) Guinier (i.e. P. deltoides Bartr. $\times$ P. nigra L.). Cultivar Fritzi Pauley is a pure P. trichocarpa Torr. \& Gray (native from North America), cv. Rap is a hybrid between this species and $P$. deltoides (native from North America) and cv. NL 2842 is a hybrid between $P$. deltoides and P. maximowiczii Henry (from Japanese origin). MAGNANI (1965) described a $P$. deltoides cultivar completely resistant to $M$. allii-populina. Thus, we can conclude that race-specific resistance to $M$. alliipopulina is inherited, at least, from both North American species $P$. deltoides and $P$. trichocarpa. In the case of $M$. larici-populina, race-specific resistance was described in $P$. deltoides, whereas none was known in $P$. trichocarpa (LEFĖVRE et al. 1994, 1995). Among the cultivars showing race-specific resistance to $M$. allii-populina, several have already been described to exhibit race-specific resistance to $M$. larici-populina: cvs Carpaccio, Cima, Isières, Luisa Avanzo, NL 2842, Rap and Spijk (PINON 1995). They all inherited their racespecific resistance from their $P$. deltoides parent. This suggests that race-specific resistance to both Melampsora species may be found in the same species and in the same cultivars. Furthermore, cv. Beaupré (susceptible to all isolates) has cv. Fritzi Pauley as female parent (V. STEENACKERS, pers. com.), which suggests that race-specific resistance is not necessarily expressed in the interspecific hybrid.

For the two Melampsora species we still have no evidence of race-specific resistance in the indigenous host $(P$. nigra) which has co-evolved with the European rust fungi. This situation appears unique since, in many pathosystems, race-specific resistance is commonly found in the native host populations (BURDON 1993, 1994; SICARD 1996). It will be necessary in future to collect many $P$. nigra clones and to inoculate them with various isolates of $M$. allii-populina and $M$. larici-populina to investigate the possible existence of race-specific resistance within $P$. nigra.

With the existence of many different virulences and of two or three formae speciales, these results indicate that $M$. allii-populina is a very polymorphic species for its pathogenicity. Consequently, breeding for complete resistance to this species would be very risky.

\section{Acknowledgements}

We are grateful to A. Schipfer, D. MASSON, K. El KARKouri, and C. ViÉNOT for their technical assistance and to D. LE THIEC for the scanning electron microscopy photograph. 


\section{Résumé}

Variabilité du pouvoir pathogène de Melampsora allii-populina vis-à-vis de cultivars de peuplier

Une collection de 42 isolats de Melampsora allii-populina a été constituée pour en étudier le pouvoir pathogène sur divers cultivars de peuplier. D’une part, quatorze isolats ont été prélevés sur divers cultivars de peuplier dans différentes localités en France. D'autre part, vingt-huit isolats ont été obtenus sur des hôtes alternants (Allium spp., Arum spp. et Muscari comosum) infectés naturellement ou inoculés à partir de feuilles portant des téleutosores de $M$. allii-populina. Aucun isolat ne s'est avéré pathogène sur la totalité des cultivars inoculés et de nombreux cas d'interactions qualitatives entre isolats et cultivars ont été mis en évidence. Ces résultats apportent la première preuve de l'existence de races physiologiques chez ce champignon. Aucun lien n'est apparu entre le pouvoir pathogène sur peuplier (virulences) et celui sur les hôtes alternants (formes spéciales). Ceci suggère que les gènes gouvernant le pouvoir pathogène sur ces deux types d'hôtes sont distincts. Parmi les cultivars inoculés, trois au moins ont été infectés par tous les isolats (Beaupré, Candicans et Robusta) alors que d'autres cultivars manifestaient des interactions qualitatives avec les isolats: Altichiero, Carpaccio, Cima, Fritzi Pauley, I 154, Isières, Luisa Avanzo, NL 2842, Rap et Spijk. La résistance spécifique à $M$. allii-populina semble être héritée au moins de deux espèces nord-américaines qui n'ont jamais co-évolué avec le parasite: Populus deltoides et Populus trichocarpa. Une comparaison est établie avec $M$. larici-populina.

\section{Zusammenfassung}

Variabilität der Pathogenität von Melampsora allii-populina gegenüber Pappelsorten

Es wurde eine Sammlung von 42 Isolaten von Melampsora allii-populina angelegt, um deren Pathogenität gegenüber verschiedenen Pappelsorten zu untersuchen. 14 Isolate stammten von verschiedenen Pappelsorten aus unterschiedlichen Gebieten Frankreichs, 28 Isolate wurden aus natürlich infizierten oder inokulierten Nebenwirten (Allium spp., Arum spp. und Muscari comosum) gewonnen. Diese Isolate wurden im Labor auf Blattstücke einer grossen Zahl von Pappelsorten, die zu mehreren Arten gehören, inokuliert. Kein Isolat war gegenüber allen Sorten pathogen, und viele qualitative Unterschiede in den Interaktionen zwischen den Isolaten und Sorten wurden beobachtet. Dies ist der Erstnachweis für die Existenz von physiologischen Rassen bei $M$. allii-populina. Zwischen der Pathogenität auf Pappeln und den Nebenwirten konnte kein Zusammenhang gefunden werden. Von den inokulierten Sorten waren zumindest drei anfällig gegenüber allen Isolaten (Beaupré, Candicans und Robusta). Hingegen zeigten die folgenden Sorten qualitiv unterschiedliche Reaktionen auf die verschiedenen Pilzisolate: Altichiero, Carpaccio, Cima, Fritzi Pauley, I 154, Isière, Luisa Avanzo, NL 2842, Rap und Spijk. Bei zwei nordamerikanischen Arten (Populus deltoides und Populus trichocarpa), die keine Coevolution mit diesem Pilz hatten, wurde eine rassenspezifische Resistenz gegenüber $M$. allii-populina gefunden (d.h. Resistenz gegenüber einigen Rassen des Pathogens, nicht jedoch gegenüber anderen). Die Ergebnisse werden im Vergleich zu Melampsora larici-populina diskutiert.

\section{References}

Agrios, G. N., 1988: Plant Pathology, 3rd edn. San Diego: Academic Press Inc.

BuRDON, J. J., 1993: The structure of pathogen populations in natural plant communities. Annu. Rev. Phytopathol. 31, 305-323.

-, 1994: The distribution and origin of genes for race-specific resistance to Melampsora lini in Linum marginale. Evolution 48, 1564-1575.

Dupias, G., 1965: Les rouilles des peupliers dans les Pyrénées et le Bassin sous-pyrénéen. Bull. Soc. Mycol. Fr. 81, 188-196.

Flor, H. H., 1935: Physiologic specialization of Melampsora lini on Linum usitatissimum. J. Agr. Res. 51, 819-837.

Lefèvre, F.; Chartier, S.; Faivre-Rampant, P.; Forestier, O.; Goué, M.-C.; Lacan, D.; Laurans, F.; Pillate, G.; PinOn, J.; Valadon, A.; Villar, M., 1995: Composantes de la résistance aux rouilles chez les peupliers: utilisation en sélection. C. R. Acad. Agric. Fr. 81, 111-121.

-; PICHOT, C.; PINON, J., 1994: Intra- and interspecific inheritance of some components of the resistance to leaf rust (Melampsora larici-populina Kleb.) in poplars. Theor. Appl. Genet. 88, 501-507.

MaGNANi, G., 1965: Indagini sulla eventuale specializzazione fisiologica in Melampsora allii-populina Kleb. Cent. Sper. Agric. For. 8, 128-133.

MCINTOSH, R. A.; WATSON, I. A., 1982: Genetics of host-pathogen interactions in rusts. In: The Rust Fungi. Ed. by SCOTT, K. J.; ChakravorTy, A. K. London: Academic Press, pp. 121-149.

PINON, J., 1992: Variability in the genus Populus in sensitivity to Melampsora rusts. Silvae Genet. 41, 25-34. 
-; 1995: Varibilitê des rouilles du Peuplier et évolution de leurs populations. Conséquences sur les stratégies de lutte. C. R. Acad. Agric. Fr. 81, 99-109.

-; BACHACOU, J., 1984: Existence de deux groupes d'isolats différant par leur pouvoir pathogène chez Melampsora larici-populina Kleb. C. R. Acad. Agric. Fr. 70, 114-122.

-; LeFÈvRE, F., 1994: A new virulence found among isolates of M. larici-populina. FAO-CIP Meeting of the Working Group of Diseases, Izmit, Turkey, 3-7 Oct. 1994.

-; Peulon, V., 1989: Mise en évidence d'une troisième race physiologique de Melampsora laricipopulina Kleb. en Europe. Cryptogam. Mycol. 10, 95-106.

-; Valadon, A., 1997: Comportement des cultivars de peuplier commercialisables dans l'Union européenne vis-à-vis de quelques parasites majeurs. Ann. Sci. For. 54, 19-38.

-; VAN DAM, B. C.; GENETET, I.; DE KAM, 1987: Two pathogenic races of Melampsora larici-populina in north-western Europe. Eur. J. For. Path. 17, 47-53.

SICARD, D., 1996: Structure génétique des populations de Colletotricbum lindemutbianum dans les centres de diversité de son hôte, Phaseolus vulgaris L. Ph.D. thesis, University of Paris XI-Orsay, France.

Steenackers, M.; Steenackers, V.; Delporte, T., 1994: A new race of $M$. larici-populina in Belgium. FAO-CIP meeting of the working group of diseases, Izmit, Turkey, 3-7 Oct. 1994.

STEENACKeRS, V., 1982: Nouvelle race physiologique de $M$. larici-populina en Belgique. FAO-CIP meeting of the working group of diseases, Casale Monferrato, Italy, 6-10 Sept. 1982.

VAN VLOTEN, H. 1949: Kruisingsproeven met rassen van Melampsora larici-populina Klebahn. Tijdschr. Pl. Ziekt. 55, 196-209.

VIENNOT-BOURGIN, G. 1937: Contribution à l'étude de la flore cryptogamique du Bassin de la Seine $\left(11^{\mathrm{C}}\right.$ note). Deux urédinées nouvelles. Rev. Path. Veg. Entomol. Agric. Fr. 24, 78-85. 